\title{
HAS THE STABILITY AND GROWTH PACT IMPEDED POLITICAL BUDGET CYCLES IN THE EUROPEAN UNION?
}

\author{
MARK MINK \\ JAKOB DE HAAN
}

CESIFO WORKING PAPER NO. 1532

CATEgory 2: Public CHOICE

SEPTEMBER 2005

An electronic version of the paper may be downloaded

- from the SSRN website:

www.SSRN.com

- from the CESifo website:

www.CESifo-group.de 


\title{
HAS THE STABILITY AND GROWTH PACT IMPEDED POLITICAL BUDGET CYCLES IN THE EUROPEAN UNION?
}

\begin{abstract}
This paper examines whether there is a political budget cycle (PBC) in countries in the euro area. Using a multivariate model for the period 1999-2004 and various election indicators we find strong evidence that the Stability and Growth Pact has not restricted fiscal policy makers in the euro area in pursuing expansionary policies before elections. In an election-year - but not in the year prior to the election - the budget deficit increases. This result is in line with third generation PBC models, which are based on moral hazard. We also find a significant but small partisan effect on fiscal policy outcomes.
\end{abstract}

JEL Code: D72, E62, D78.

Keywords: fiscal policy, political budget cycle, Stability and Growth Pact.

Mark Mink

University of Groningen, the Netherlands

Faculty of Economics

PO Box 800

9700 AV Groningen

The Netherlands
Jakob de Haan

University of Groningen, the Netherlands

Faculty of Economics

PO Box 800

9700 AV Groningen

The Netherlands

jakob.de.haan@rug.nl 


\section{Introduction}

It is often thought that incumbents try to use expansionary fiscal policy before elections to increase their popularity. However, most empirical studies examining the existence of a political budget cycle $(\mathrm{PBC})^{1}$ in industrial countries find little support for such election-driven fiscal policy manipulations. ${ }^{2}$ As Brender and Drazen (2005) point out, until recently a PBC was generally thought to be a phenomenon of less developed economies. For instance, Schuknecht (1996) reports evidence for a PBC in his sample of 35 developing countries over the period 1970-92. ${ }^{3}$ In addition, Block (2002) finds for a cross-section of 44 Sub-Saharan African countries that the government fiscal deficit increases by 1.2 percentage points in election years.

However, some recent studies present evidence for the existence of a $\mathrm{PBC}$ in a large cross-section of both developed and developing countries. For instance, Shi and Svensson (2002) show that significant pre-electoral increases in the government budget deficit exist for their panel of 91 developing and developed countries over the period 1975-95. Moreover, Persson and Tabellini (2002) report statistically significant tax decreases before elections in a sample of 60 democracies over the period 1960-98. Brender and Drazen (2005) pose, however, that the results of these studies are driven by the experience of so-called "new democracies", where fiscal manipulation may be effective because of lack of experience with electoral politics in these countries. They argue that once the "new democracies" are removed from the sample, the PBC disappears. Nonetheless, also some recent studies focusing on "established democracies" find evidence for the existence of a PBC. ${ }^{4}$

Some of these studies examine whether a PBC exists in member countries of the European Union (EU). Andrikopoulos et al. (2004) investigate whether incumbent governments manipulated fiscal policy in order to enhance re-election perspectives. Their empirical evidence for the 1970-1998 period does not support this hypothesis. ${ }^{5}$ Still, other studies focusing on the "old" member countries of the EU claim that in more recent years fiscal policy often turned expansionary before elections. For instance, Buti and van den Noord (2003) come to this

\footnotetext{
${ }^{1}$ A political budget cycle is a periodic fluctuation in a government's fiscal policies, which is induced by the cyclicality of elections. Shi and Svensson (2004) review some recent developments in the theory and evidence of these cycles. See also Franzese (2002) and Drazen (2000) for extensive reviews of the literature.

${ }^{2}$ There are exceptions, however. For instance, Alesina et al. (1997), who perform cross-section time series regressions on a panel of 13 OECD countries for the period between 1961 and 1993, find that the government budget deficit is 0.6 percent of GDP higher in election years. Also Franzese (2000) reports evidence for electoral manipulation of fiscal policy in his sample of 20 OECD countries.

${ }^{3}$ Likewise, Schuknecht (2000) finds for a sample of twenty-four developing countries for the 1973-1992 period that incumbent governments tend to increase public investment prior to elections.

${ }^{4}$ For instance, Tujula and Wolswijk (2004) find support for a PBC in their sample of OECD countries for the period 1970-2002. Alt and Lassen (2005) argue that among advanced democracies significant opportunistic electoral cycles are conditional on the transparency of budget institutions. In countries with less transparent institutions the electoral cycle in fiscal policy appears, while no such election-related fiscal policy movements show up in higher-transparency countries.

${ }^{5}$ Also De Haan and Sturm (1994) find no support for PBCs in their analysis of fiscal policy in EU member countries.
} 
conclusion based on an examination of the discretionary part of fiscal policy over the 1999-2002 period. Also von Hagen (2003) concludes that there is evidence for a PBC in EU member countries. For the period 1998-2002 he finds that the (unweighted) average fiscal impulse in preelection years is significantly higher than the average fiscal impulse in all other country-year cases. $^{6}$

The results of these last two papers are perhaps somewhat surprising since member countries of the EU are restricted in their fiscal policies by the Stability and Growth Pact (SGP). The SGP consists of two Council Regulations: one on the strengthening of the surveillance and co-ordination of budgetary positions, and the other on speeding up and clarifying the implementation of the excessive deficit procedure. A corresponding European Council Resolution ties them together. Regulation 1466/97 sets out to strengthen multilateral surveillance and gives member states a goal of a medium term budgetary position of close to balance or in surplus. Regulation 1467/97 clarifies and accelerates the excessive deficit procedure as specified in the Maastricht Treaty so that - in principle - within 10 months non-interest bearing deposits and ultimately fines can be imposed in case the member state concerned takes no effective actions to redress so-called excessive deficits (measured against reference values of 3\% of GDP for the general government budget deficit and $60 \%$ for the general government debt-to-GDP ratio). ${ }^{7}$ According to Buti and van den Noord (2003, p. 4), the SGP "is unquestionably the most stringent supranational 'commitment technology' ever adopted by sovereign governments on a voluntary basis in the attempt to establish and maintain sound public finances. The SGP, if applied according to its letter and spirit, will have important implications for the behaviour of budgetary authorities in both the short term (cyclical stabilisation, policy co-ordination) and long term (sustainability of public finances)."

This paper examines whether there really exists a PBC in EU member countries in the euro area. We focus on EU members that have adopted the euro since the rules of the SGP are less strict for member countries that are not part of the currency union. In contrast to Buti and van den Noord (2003) and von Hagen (2003) we use a multivariate model. Furthermore, instead of employing election dummies - like most previous PBC studies - we use an election variable suggested by Franzese (2000) that takes the timing of an election in the course of a year into account. On the basis of data for the period 1999-2004 we find strong evidence that the SGP has not restricted fiscal policy makers in the euro area in pursuing expansionary policies before elections. In an election-year - but not in the year prior to the election - the budget deficit

\footnotetext{
${ }^{6}$ However, the evidence of von Hagen is not very convincing. For instance, he takes both presidential and parliamentary elections into account even though presidents in some countries have hardly any influence on policymaking. De Haan et al. (2003) could not replicate his findings.

${ }^{7}$ See Amtenbrink and De Haan (2003) for an extensive discussion of the SGP. De Haan et al. (2004) examine the weaknessess of the SGP. See also Schuknecht (2004).
} 
increases. This result is in line with third generation PBC models, which are based on moral hazard. We also find that the political composition of the government has a significant (but small) influence on net lending.

The remainder of the paper is organized as follows. Section 2 offers some theoretical considerations, while section 3 outlines the empirical model. Section 4 contains the main results and section 5 presents the outcomes of various sensitivity tests. The final section offers some concluding comments.

\section{Theoretical considerations ${ }^{8}$}

Three generations of theoretical PBC models can be distinguished. The first generation models emphasize the incumbent's intention to secure re-election by maximizing its expected vote share at the next election (Nordhaus, 1975). It is assumed that the electorate has backward-looking expectations and evaluates the government on the basis of its past track record. As a result, these models imply that governments, regardless of ideological orientation, adopt expansionary fiscal policies in the late year(s) of their term in office in order to stimulate the economy.

The second generation models - Shi and Svensson (2004) call them adverse selection-type models - emphasize the role of temporary information asymmetries regarding the politicians' competence level in explaining electoral cycles in fiscal policy. In these models, signalling is the driving force behind the PBC. The first of these models is due to Rogoff and Sibert (1988), who assume that each political candidate has a competence level (high or low), which is only known to the politician and not to the electorate. Voters want to elect the more competent politician and form rational expectations regarding the incumbent's type based on observable current fiscal policy outcomes. Before the election, the high-type incumbent will attempt to signal his type (and thereby increase his chances of re-election) by engaging in expansionary fiscal policy, which is less "costly" for him than it is for the low type. This leads to a pre-election increase in the government deficit when a competent politician is in office. ${ }^{9}$ As pointed out by Shi and Svensson (2004), some of the implications of the signalling models seem to be at odds with both empirical and anecdotal evidence. For example, only the more competent politician (rather than the less competent one) distorts the economy in the separating equilibrium of the signalling game. Likewise, only competent politicians will be re-elected. Furthermore, since only competent types signal by creating a boom before an election, the testable implications are unclear without additional information on the (unobservable) type of the incumbent.

\footnotetext{
${ }^{8}$ This section heavily draws on Andrikopoulos et al. (2004) and Shi and Svensson (2004).

${ }^{9}$ Rogoff (1990) argues that the incumbent can also signal his competence before an election by shifting government expenditure towards easily observed consumption spending and away from investment.
} 
These drawbacks do not apply to the third generation PBC models, which are based on moral hazard. Examples of such studies are Persson and Tabellini (2000) and Shi and Svensson (2002). As in the adverse selection models, it is assumed that each politician has some competence level which is unknown to the electorate. However, in addition it is assumed that also the politician himself cannot ex ante observe this competence level. Therefore, politicians are uncertain about how well they will be able to handle future problems. Voters are rational and want to elect the most competent politician since that would imply higher post-election public goods production. Their inference is based on the observable macroeconomic performance of the incumbent government. The key assumption is that the incumbent government can exert a hidden effort, that is, to use a policy instrument unobservable to the public, which is a substitute for competence. For example, if competence measures how well the politician can convert revenues into public goods, then the hidden effort can be interpreted as the government's short-term excess borrowing. Elections take place after the incumbent government's hidden effort and competence have jointly determined the observable macroeconomic outcome. The incumbent government would like to increase its performance index by exerting more effort (borrow more), hoping that voters would attribute the boost in public goods provision to its competence. In the equilibrium of this moral hazard game, there will be an excessive effort on the part of the incumbent politician, and as a result there is an increase in the budget deficit prior to an election. In these models all types of incumbent governments will incur excessive pre-election budget deficits (independent of their competence level). As Shi and Svensson (2004) point out, one can test these empirical predictions no matter whether the type of the incumbent government is observable. Furthermore, the implications of this model can be tested for all countries that have elections, irrespective of their political structure (e.g. the existence of partisan differences).

\section{Empirical model and data}

Apart from electoral influences, we take two factors into account in our empirical model that are not controlled by policy makers but affect fiscal policy outcomes. First, we include the output gap as a proxy for the business cycle. An economic upswing will lead to an increase in the budget balance, while in the downward phase of the business cycle the balance usually deteriorates. As there is no consensus in the literature how to construct the output gap, we use output gaps based on potential GDP as well as output gaps calculated on the basis of trend GDP (employing a Hodrick-Prescott filter).

Second, since unforeseen economic developments may affect fiscal policy outcomes we include the difference between actual and expected real GDP growth. The expected growth rates are the GDP forecasts as available at the time the government budget was decided upon. A higher 
than expected growth rate will lead to an increase in the budget balance due to, amongst others, unexpected increases in tax receipts. Likewise, unexpected inflation may have an effect on the budget balance. As pointed out by Tujula and Wolswijk (2004), inflation may affect government receipts and expenditures through nominal progression in tax rates and tax brackets, and via priceindexation of receipts and expenditures. On the other hand unexpected inflation erodes the real value of nominal government debt so that the overall effect of inflation on the budget balance is not clear a priori.

After accounting for the effects of business cycle fluctuations and forecasting errors in GDP growth and inflation, all remaining changes in the budget balance are considered to be the result of discretionary fiscal policy. These considerations suggests estimating the following equation:

$$
\Delta \mathrm{BB}_{\mathrm{it}}=\beta_{0}+\beta_{1}\left(\mathrm{y}_{\mathrm{it}}-\mathrm{y}_{\mathrm{it}}^{\mathrm{f}}\right)+\beta_{2}\left(\pi_{\mathrm{it}}-\pi_{\mathrm{it}}^{\mathrm{f}}\right)+\beta_{3}\left(\Delta \mathrm{GAP}_{\mathrm{it}}\right)+\beta_{4}(\text { Election Measure })+\varepsilon_{\mathrm{it}}
$$

where:

$\Delta \mathrm{BB}_{\mathrm{it}}=\quad$ the change in the overall budget balance as measured by the change in
$\mathrm{y}_{\mathrm{it}}-\mathrm{y}_{\mathrm{it}}^{\mathrm{f}}=\quad$ net lending;
the difference between actual real GDP growth at time $\mathrm{t}$ and real growth
$\pi_{\mathrm{it}}-\pi_{\mathrm{it}}^{\mathrm{f}}=\quad \begin{aligned} & \text { as forecasted at the time fiscal policy for year } \mathrm{t} \text { was determined; } \\ & \Delta \mathrm{GAP}_{\mathrm{it}} \quad=\quad \text { the difference between actual inflation at time } \mathrm{t} \text { and inflation as }\end{aligned}$
forecasted at the time fiscal policy for year $\mathrm{t}$ was determined;

In order to take account of potential election effects, two alternative indicators are considered. The first involves adding a dummy to the equation which indicates whether a year is an election-year or not. A similar dummy will be used to account for pre-election years. As fiscal policy decisions may take some time to have an effect, election-induced fiscal measures could be taken in the year prior to the actual election.

The second indicator takes the timing of an election in the course of the year into account. It has been developed by Franzese (2000) and is calculated as

$$
\mathrm{ELE}_{\mathrm{it}}=[(\mathrm{M}-1)+\mathrm{d} / \mathrm{D}] / 12
$$

where $\mathrm{M}$ is the month of the election, $\mathrm{d}$ is the day of the election and $\mathrm{D}$ is the number of days in that month. For the year prior to the election year the indicator is calculated as: 


$$
\mathrm{ELE}_{\mathrm{it}}=[12-(\mathrm{M}-1)-\mathrm{d} / \mathrm{D}] / 12
$$

In all other years its value is set to zero. ${ }^{10}$

The macroeconomic data necessary to estimate the model have been obtained from stability programmes of the EU countries and official publications of the European Commission. Data on general election dates are mainly taken from political data yearbooks (Katz and Koole (1999, 2000, 2001, 2002, 2003) and Van Biezen and Katz (2004)). The sample contains observations for all twelve countries in the euro area ${ }^{11}$ over the time period 1999 to 2004 . The appendix contains a detailed overview of the data sources used.

\section{Results}

Columns I and II of Table 1 present benchmark regressions that only contain the economic control variables. The difference between the regressions is the output gap variable used; in column I this variable is constructed on the basis of potential output, while in column II it is calculated on the basis of trend income. It follows that only the coefficients for the output gap measures are significantly different from zero.

\footnotetext{
${ }^{10}$ For reasons that become clear later, we want to be able to interpret the values of the election indicator in terms of actual election dates. This means that an indicator value of, for instance, $7 / 12$ in an election year as well as a value of $5 / 12$ in a pre-election year imply elections take place at the end of July. For consistency, this requires that snap elections are ignored because in that case election-driven policy manipulations can only occur in the period between the government crisis and the election.

${ }^{11}$ The countries in the euro area are Austria, Belgium, Finland, France, Germany, Greece, Ireland, Italy, Luxembourg, The Netherlands, Portugal and Spain.
} 
Table 1. Estimation results - Election dummy

\begin{tabular}{|c|c|c|c|c|c|c|c|c|}
\hline $\begin{array}{l}\text { Dependent Variable } \\
\text { Equation Nr. }\end{array}$ & \multicolumn{8}{|c|}{$\Delta \mathrm{BB}_{\mathrm{it}}$} \\
\hline $\mathrm{C}$ & $\begin{array}{c}0.0611 \\
(0.5072)\end{array}$ & $\begin{array}{c}0.0306 \\
(0.7422)\end{array}$ & $\begin{array}{c}0.1454 \\
(0.1568)\end{array}$ & $\begin{array}{c}0.1109 \\
(0.2871)\end{array}$ & $\begin{array}{c}0.2818 \\
(0.0002)^{\star \star \star}\end{array}$ & $\begin{array}{c}0.2515 \\
(0.0011)^{\star \star \star}\end{array}$ & $\begin{array}{c}0.4126 \\
(0.0000)^{\star \star \star}\end{array}$ & $\begin{array}{c}0.3820 \\
(0.0001)^{\star \star \star}\end{array}$ \\
\hline$y_{i t}-y_{i t}^{f}$ & $\begin{array}{c}0.2233 \\
(0.1503)\end{array}$ & $\begin{array}{c}0.1813 \\
(0.2474)\end{array}$ & $\begin{array}{c}0.2339 \\
(0.1247) \\
\end{array}$ & $\begin{array}{c}0.2093 \\
(0.1744)\end{array}$ & $\begin{array}{c}0.3420 \\
(0.0044)^{\star \star \star}\end{array}$ & $\begin{array}{c}0.3174 \\
(0.0101)^{\star \star}\end{array}$ & $\begin{array}{c}0.3292 \\
(0.0107)^{\star \star}\end{array}$ & $\begin{array}{c}0.3162 \\
(0.0190)^{\star *}\end{array}$ \\
\hline$\pi_{i t}-\pi_{i t}^{\mathrm{f}}$ & $\begin{array}{l}-0.0350 \\
(0.8070)\end{array}$ & $\begin{array}{l}-0.0743 \\
(0.5894) \\
\end{array}$ & $\begin{array}{l}-0.0246 \\
(0.8816) \\
\end{array}$ & $\begin{array}{l}-0.0670 \\
(0.6864)\end{array}$ & $\begin{array}{l}-0.0332 \\
(0.7547)\end{array}$ & $\begin{array}{l}-0.0473 \\
(0.6383)\end{array}$ & $\begin{array}{l}-0.0759 \\
(0.5882) \\
\end{array}$ & $\begin{array}{l}-0.0917 \\
(0.5202)\end{array}$ \\
\hline$\Delta \mathrm{GAP}_{\mathrm{it}}^{\text {Potential GDP }}$ & $\begin{array}{c}0.2496 \\
(0.0702)^{\star}\end{array}$ & - & $\begin{array}{c}0.2335 \\
(0.1084)\end{array}$ & - & $\begin{array}{c}0.1898 \\
(0.0593)^{\star}\end{array}$ & - & $\begin{array}{c}0.1723 \\
(0.1296)\end{array}$ & - \\
\hline$\Delta \mathrm{GAP}_{\mathrm{it}}^{\text {Trend GDP }}$ & - & $\begin{array}{c}0.3055 \\
(0.0203)^{\star \star}\end{array}$ & - & $\begin{array}{c}0.2740 \\
(0.0434)^{\star \star}\end{array}$ & - & $\begin{array}{c}0.2180 \\
(0.0298)^{\star \star}\end{array}$ & - & $\begin{array}{c}0.1871 \\
(0.1018)\end{array}$ \\
\hline $\mathrm{D}_{\mathrm{it}}^{\text {Pre-election year }}$ & - & - & $\begin{array}{c}-0.4928 \\
(0.0775)^{\star}\end{array}$ & $\begin{array}{l}-0.4569 \\
(0.1014)\end{array}$ & - & - & $\begin{array}{c}-0.5814 \\
(0.0134)^{\star \star}\end{array}$ & $\begin{array}{c}-0.5597 \\
(0.0184)^{\star *}\end{array}$ \\
\hline $\mathrm{D}_{\mathrm{it}}^{\text {Election year }}$ & - & - & - & - & $\begin{array}{c}-0.9541 \\
(0.0000)^{\star \star \star}\end{array}$ & $\begin{array}{c}-0.9284 \\
(0.0000)^{\star \star \star}\end{array}$ & $\begin{array}{c}-0.9726 \\
(0.0000)^{\star \star \star}\end{array}$ & $\begin{array}{c}-0.9556 \\
(0.0000)^{\star \star \star}\end{array}$ \\
\hline Durbin-Watson Stat. & 2.13 & 2.17 & 2.18 & 2.21 & 2.04 & 2.04 & 2.18 & 2.18 \\
\hline Adjusted $\mathrm{R}^{2}$ & 0.20 & 0.22 & 0.25 & 025 & 0.46 & 0.47 & 0.45 & 0.44 \\
\hline
\end{tabular}

Note: Balanced sample of 72 observations and 12 cross sections; panel generalized least squares (cross-section weights) with common effects (F-test does not reject estimating a common intercept instead of fixed effects); White heteroskedasticity consistent standard errors \& covariance; p-values between parentheses: *, ** and $* * *$ denote significance at $10 \%, 5 \%$ and $1 \%$ level, respectively. 
In columns III and IV a pre-election year dummy is added to the model. In both specifications the election coefficients have a negative sign but are not very significant. Moreover, the fit of the model does not improve substantially compared to the benchmark regressions. However, this changes when the pre-election year dummy is replaced by an election year dummy (columns V and VI). Now the adjusted R-squared rises to about 0.46 and the election effect is highly significant. Also an unexpected increase in GDP growth has a positive and significant effect on the budget balance. However, the coefficient of unexpected inflation remains insignificant. Finally, columns VII and VIII of Table 1 present specifications in which preelection as well as election year dummies are included. The pre-election year dummy becomes somewhat more significant than before, but the fit of the model decreases slightly compared to the specification in which only an election year dummy is taken into account.

Table 2 presents the results that are obtained when possible election effects are modelled more accurately, that is, by means of the election indicator as suggested by Franzese (2000). In columns I and II an indicator is added, labelled with the superscript 'standard', which comprises both pre-election and election years. The coefficients of the output gap and unexpected GDP growth are significantly different from zero. There is also a highly significant election effect. If the election variable is decomposed into separate effects for pre-election and election years, the same pattern as in Table 1 becomes visible. Columns III and IV of Table 2 show that there is no effect in the pre-election year, while columns V and VI indicate the existence of a highly significant effect during the election year. This is underlined by the high adjusted R-squared. Columns VII and VIII of Table 2 show that including the two indicators simultaneously does not lead to a significant effect during pre-election years.

So our results suggest that only during the election year the budget deficit increases. This increase amounts to $0.96 \%$ of GDP according to the model with the election year dummy and $0.83 \%$ of GDP according to the model with the election-year indicator. ${ }^{12}$ The latter figure is obtained trough multiplication of the coefficient estimate for the election year indicator obtained in column VI of Table 2, with the average value of the indicator over all election years, which is 0.38 in our sample.

\footnotetext{
12 This conclusion is not affected by the exclusion of snap elections in calculating the election indicators (results available on request).
} 
Table 2. Estimation results - Election indicator

\begin{tabular}{|c|c|c|c|c|c|c|c|c|}
\hline \multirow{2}{*}{$\begin{array}{l}\text { Dependent Variable } \\
\text { Equation Nr. }\end{array}$} & \multicolumn{8}{|c|}{$\Delta \mathrm{BB}_{\mathrm{it}}$} \\
\hline & I & II & III & IV & $\mathrm{V}$ & VI & VII & VIII \\
\hline $\mathrm{C}$ & $\begin{array}{c}0.2589 \\
(0.0069)^{\star \star \star}\end{array}$ & $\begin{array}{c}0.2154 \\
(0.0238)^{\star \star}\end{array}$ & $\begin{array}{c}0.0810 \\
(0.4294)\end{array}$ & $\begin{array}{c}0.0453 \\
(0.6634)\end{array}$ & $\begin{array}{c}0.2346 \\
(0.0008)^{\star \star \star}\end{array}$ & $\begin{array}{c}0.2039 \\
(0.0042)^{\star \star \star}\end{array}$ & $\begin{array}{c}0.2796 \\
(0.0008)^{\star \star \star}\end{array}$ & $\begin{array}{c}0.2409 \\
(0.0039)^{\star \star \star}\end{array}$ \\
\hline $\mathrm{y}_{\mathrm{it}}-\mathrm{y}_{\mathrm{it}}^{\mathrm{f}}$ & $\begin{array}{c}0.2607 \\
(0.0520)^{\star}\end{array}$ & $\begin{array}{c}0.2405 \\
(0.0734)^{\star}\end{array}$ & $\begin{array}{c}0.2202 \\
(0.1556) \\
\end{array}$ & $\begin{array}{c}0.1914 \\
(0.2230)\end{array}$ & $\begin{array}{c}0.3203 \\
(0.0061)^{\star \star \star}\end{array}$ & $\begin{array}{c}0.2935 \\
(0.0130)^{\star \star}\end{array}$ & $\begin{array}{c}0.3039 \\
(0.0134)^{\star \star}\end{array}$ & $\begin{array}{c}0.2876 \\
(0.0221)^{\star \star}\end{array}$ \\
\hline$\pi_{i t}-\pi_{i t}^{f}$ & $\begin{array}{l}-0.0143 \\
(0.9354)\end{array}$ & $\begin{array}{l}-0.0553 \\
(0.7200)\end{array}$ & $\begin{array}{l}-0.0345 \\
(0.8324) \\
\end{array}$ & $\begin{array}{l}-0.0761 \\
(0.6383)\end{array}$ & $\begin{array}{l}-0.0246 \\
(0.8205)\end{array}$ & $\begin{array}{l}-0.0501 \\
(0.6225)\end{array}$ & $\begin{array}{l}-0.0176 \\
(0.8958) \\
\end{array}$ & $\begin{array}{l}-0.0504 \\
(0.7075)\end{array}$ \\
\hline$\Delta \mathrm{GAP}_{\mathrm{it}}^{\text {Potential GDP }}$ & $\begin{array}{c}0.2558 \\
(0.0253)^{\star \star}\end{array}$ & - & $\begin{array}{c}0.2575 \\
(0.0731)^{\star}\end{array}$ & - & $\begin{array}{c}0.2363 \\
(0.0215)^{\star \star}\end{array}$ & - & $\begin{array}{c}0.2641 \\
(0.0172)^{\star \star}\end{array}$ & $\begin{array}{c}0.2724 \\
(0.0105)^{\star \star}\end{array}$ \\
\hline$\Delta \mathrm{GAP}_{\mathrm{it}}^{\text {Trend GDP }}$ & - & $\begin{array}{c}0.3063 \\
(0.0094)^{\star \star \star}\end{array}$ & - & $\begin{array}{c}0.2973 \\
(0.0276)^{\star \star \star}\end{array}$ & - & $\begin{array}{c}0.2603 \\
(0.0085)^{\star \star \star}\end{array}$ & - & - \\
\hline $\mathrm{ELE}_{\mathrm{it}}^{\text {Standard }}$ & $\begin{array}{c}-1.2285 \\
(0.0007)^{\star \star \star}\end{array}$ & $\begin{array}{c}-1.1732 \\
(0.0012)^{\star \star \star}\end{array}$ & - & - & - & - & - & - \\
\hline $\mathrm{ELE}_{\mathrm{it}}^{\text {Pre-election year }}$ & - & - & $\begin{array}{l}-0.3778 \\
(0.3745) \\
\end{array}$ & $\begin{array}{l}-0.3229 \\
(0.4352)\end{array}$ & - & - & $\begin{array}{l}-0.6139 \\
(0.1023) \\
\end{array}$ & $\begin{array}{l}-0.5648 \\
(0.1262)\end{array}$ \\
\hline ELE $_{\text {it }}^{\text {Election year }}$ & - & - & - & - & $\begin{array}{c}-2.2148 \\
(0.0000)^{\star \star \star}\end{array}$ & $\begin{array}{c}-2.2003 \\
(0.0000)^{\star \star \star}\end{array}$ & $\begin{array}{c}-2.2595 \\
(0.0000)^{\star \star \star}\end{array}$ & $\begin{array}{c}-2.2254 \\
(0.0000)^{\star \star \star}\end{array}$ \\
\hline Durbin-Watson Stat. & 2.27 & 2.31 & 2.16 & 2.20 & 2.17 & 2.19 & 2.24 & 2.26 \\
\hline Adjusted $\mathrm{R}^{2}$ & 0.38 & 0.37 & 0.20 & 0.21 & 0.47 & 0.49 & 0.45 & 0.45 \\
\hline
\end{tabular}

Note: Balanced sample of 72 observations and 12 cross sections; panel generalized least squares (cross-section weights) with common effects (F-test does not reject estimating a common intercept instead of fixed effects); White heteroskedasticity consistent standard errors \& covariance; $p$-values between parentheses: *, ** and $* * *$ denote significance at $10 \%, 5 \%$ and $1 \%$ level, respectively. 
At first sight it seems rather peculiar that there exists such a large difference between the effects of pre-election and election years. Puzzling as it might seem, there is a plausible explanation for this phenomenon that can be derived from the third generation PBC models as outlined in section 2. In these models, it is assumed that the government uses short-term excess borrowing as a hidden effort - that is, as a policy instrument unobservable to the electorate - in order to increase its performance index. Borrowing extra money during a pre-election year is less easy to hide in comparison to borrowing during an election year since information on the preelection year's budget deficit is likely to be published prior to the election date. As a result, the policy instrument is not unobservable anymore since all excess government borrowing will be noticed by the electorate. Consequently, the increase in the government's performance index will not take place. In fact, the index might even decline if the electorate strongly prefers budgetary discipline. $^{13}$

The mechanism described above also implies that the relationship between the timing of an election during the year and electoral-induced fiscal policy manipulations is non-monotonic. There is a trade-off between two effects: a higher value of the election-year measure indicates that during that year there is ample time for the government to increase its performance index, but a higher value of the election-year variable also indicates that it will be more difficult for the government to adequately hide its efforts from the electorate since more reliable statistics on the size of the budget balance are available to the public.

To test this further, we decompose the election-year indicator into four variables. The first variable contains all values for the indicator within the interval $[0.00 ; 0.25]$, the second contains the values within $[0.25 ; 0.50]$ and the third and fourth contain the values within $[0.50 ; 0.75]$ and $[0.75 ; 1.00]$. Columns I and II of Table 3 present the results. Clearly, both models fit the data substantially better than the models estimated before, and the products of interval means and coefficient values ${ }^{14}$ indeed suggest that the relationship between the change in net lending and the value of the election year indicator is non-linear. This is further supported by the results from columns III and IV, which account for a non-linear election effect by using a squared electionyear indicator in addition to the original one. The model fit is quite good and the coefficients for the election year variables are highly significant.

\footnotetext{
${ }^{13}$ There is some evidence (see, for instance, Brender 2003) suggesting that a deterioration of the financial position of the government harms the chances of re-election faced by the incumbent. Brender (2003) argues that this should be the case in all "well developed democracies" where voters can monitor the evolution of public finances. Drazen and Eslava (2003) try to reconcile this fiscal conservativeness and the PBC.

${ }^{14}$ These are not reported here but they can easily be calculated from the information provided in Table 3 .
} 
Table 3. Estimation results - Election-year indicator with non-linear effect

\begin{tabular}{|c|c|c|c|c|c|c|}
\hline \multirow{2}{*}{$\begin{array}{l}\text { Dependent Variable } \\
\text { Equation } \mathrm{Nr} \text {. }\end{array}$} & \multicolumn{6}{|c|}{$\Delta \mathrm{BB}_{\mathrm{it}}$} \\
\hline & I & II & III & IV & $\mathrm{V}$ & $\mathrm{VI}$ \\
\hline $\mathrm{C}$ & $\begin{array}{c}0.2269 \\
(0.0000)^{\star \star \star}\end{array}$ & $\begin{array}{c}0.2121 \\
(0.0001)^{\star \star \star}\end{array}$ & $\begin{array}{c}0.2565 \\
(0.0000)^{\star \star \star}\end{array}$ & $\begin{array}{c}0.2321 \\
(0.0001)^{\star \star \star}\end{array}$ & $\begin{array}{c}-0.4433 \\
(0.0166)^{\star \star}\end{array}$ & $\begin{array}{c}-0.4102 \\
(0.0278)^{\star \star}\end{array}$ \\
\hline$y_{i t}-y_{i t}^{f}$ & $\begin{array}{c}0.3745 \\
(0.0000)^{\star \star \star}\end{array}$ & $\begin{array}{c}0.3577 \\
(0.0001)^{\star \star \star}\end{array}$ & $\begin{array}{c}0.3621 \\
(0.0002)^{\star \star \star}\end{array}$ & $\begin{array}{c}0.3444 \\
(0.0006)^{\star \star \star}\end{array}$ & $\begin{array}{c}0.3116 \\
(0.0005)^{\star \star \star}\end{array}$ & $\begin{array}{c}0.3108 \\
(0.0011)^{\star \star \star}\end{array}$ \\
\hline$\pi_{\mathrm{it}}-\pi_{\mathrm{it}}^{\mathrm{f}}$ & $\begin{array}{l}-0.0067 \\
(0.9405)\end{array}$ & $\begin{array}{l}-0.0291 \\
(0.7546)\end{array}$ & $\begin{array}{c}0.0084 \\
(0.9296)\end{array}$ & $\begin{array}{l}-0.0129 \\
(0.8867)\end{array}$ & $\begin{array}{l}-0.0354 \\
(0.6739)\end{array}$ & $\begin{array}{l}-0.0750 \\
(0.3887)\end{array}$ \\
\hline$\Delta \mathrm{GAP}_{\mathrm{it}}^{\text {Potential GDP }}$ & $\begin{array}{c}0.1956 \\
(0.0034)^{\star \star \star}\end{array}$ & - & $\begin{array}{c}0.2009 \\
(0.0138)^{\star \star}\end{array}$ & - & $\begin{array}{c}0.2981 \\
(0.0002)^{\star \star \star}\end{array}$ & - \\
\hline$\Delta \mathrm{GAP}_{\mathrm{it}}^{\mathrm{Trend} G D P}$ & - & $\begin{array}{c}0.1967 \\
(0.0062)^{\star \star \star}\end{array}$ & - & $\begin{array}{c}0.2140 \\
(0.0076)^{\star \star \star}\end{array}$ & - & $\begin{array}{c}0.2785 \\
(0.0003)^{\star \star \star}\end{array}$ \\
\hline ELE $_{\text {it }}^{\text {Election year }(0.00-0.25)}$ & $\begin{array}{l}-1.5859 \\
(0.4274) \\
\end{array}$ & $\begin{array}{l}-1.7206 \\
(0.3292)\end{array}$ & - & - & - & - \\
\hline ELE $_{\text {it }}^{\text {Election year }(0.25-0.50)}$ & $\begin{array}{c}-2.9140 \\
(0.0000)^{\star \star \star}\end{array}$ & $\begin{array}{c}-2.8959 \\
(0.0000)^{\star \star \star}\end{array}$ & - & - & - & - \\
\hline ELE $_{\text {it }}^{\text {Election year }(0.50-0.75)}$ & $\begin{array}{c}-0.7125 \\
(0.0000)^{\star \star \star}\end{array}$ & $\begin{array}{c}-0.6366 \\
(0.0000)^{\star \star \star}\end{array}$ & - & - & - & - \\
\hline ELE $_{\text {it }}^{\text {Election year (0.75-1.00) }}$ & $\begin{array}{c}-0.4279 \\
(0.0278)^{\star \star}\end{array}$ & $\begin{array}{c}-0.4588 \\
(0.0186)^{\star \star}\end{array}$ & - & - & - & - \\
\hline ELE $_{\text {it }}^{\text {Election year }}$ & - & - & $\begin{array}{c}-5.4486 \\
(0.0000)^{\star \star \star}\end{array}$ & $\begin{array}{c}-5.2460 \\
(0.0000)^{\star \star \star}\end{array}$ & $\begin{array}{c}-5.5918 \\
(0.0000)^{\star \star \star}\end{array}$ & $\begin{array}{c}-5.2627 \\
(0.0000)^{\star \star \star}\end{array}$ \\
\hline$\left(\mathrm{ELE}_{\mathrm{it}}^{\text {Election year }}\right)^{2}$ & - & - & $\begin{array}{c}6.0190 \\
(0.0001)^{\star \star \star}\end{array}$ & $\begin{array}{c}5.7320 \\
(0.0001)^{\star \star \star}\end{array}$ & $\begin{array}{c}6.4389 \\
(0.0000)^{\star \star \star}\end{array}$ & $\begin{array}{c}5.9783 \\
(0.0000)^{\star \star \star}\end{array}$ \\
\hline $\mathrm{GCOL}_{\text {it }}$ & - & - & - & - & $\begin{array}{c}0.0638 \\
(0.0002)^{\star \star \star}\end{array}$ & $\begin{array}{c}0.0582 \\
(0.0007)^{\star \star \star}\end{array}$ \\
\hline Durbin-Watson Stat. & 2.16 & 2.17 & 2.10 & 2.10 & 2.12 & 2.13 \\
\hline Adjusted $\mathrm{R}^{2}$ & 0.72 & 0.67 & 0.61 & 0.61 & 0.69 & 0.67 \\
\hline
\end{tabular}

Note: Balanced sample of 72 observations and 12 cross sections; panel generalized least squares (cross-section weights) with common effects (F-test does not reject estimating a common intercept instead of fixed effects); White heteroskedasticity consistent standard errors \& covariance; p-values between parentheses: *, ** and *** denote significance at $10 \%, 5 \%$ and $1 \%$ level respectively. 
The pattern that can be derived from the coefficient estimates for the election effect is depicted in Figure 1. The graph shows that fiscal policy becomes more expansionary when the election date moves from the start of the year towards the middle. This is a consequence of the fact that the year becomes increasingly suited for raising government popularity by means of supplying extra public goods to the electorate, while the incumbent's fiscal performance will be evaluated primarily on the basis of the past year's budget balance. However, when the election date moves further towards the end of the year information on the budget balance gradually becomes available and this increases the incentive to reduce election-driven excess short-term borrowing.

\section{Figure 1. Graphical representation of the election-year effect}

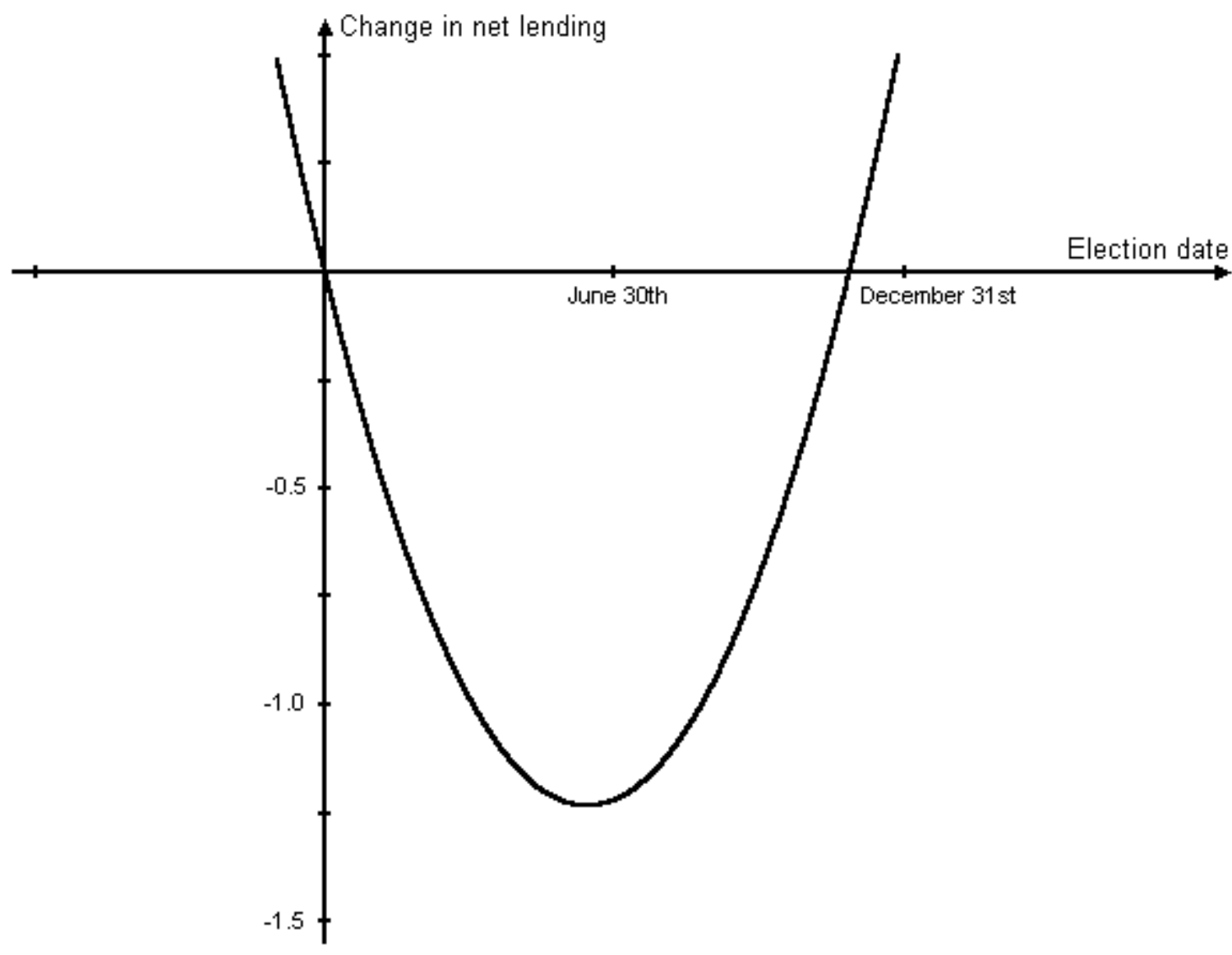

\section{Sensitivity analysis}

In order to test for the robustness of our results for sample composition, we estimated equations III and IV of Table 3 twelve times, each time excluding one country from the sample. Although 
the exclusion of France results in an insignificant coefficient for the unexpected growth variable, the election effect is always highly significant (results available on request).

We have also estimated specifications III and IV using different indicators of fiscal policy as dependent variable. First, while excluding the output gap as regressor, we used cyclically adjusted changes in net lending. Second, we used the level of net lending while adopting the output gap level instead of the change therein as a regressor. In both cases, the outcomes were highly comparable to ones originally obtained, the election-year effect being somewhat stronger under the first case while being slightly weaker under the second (results available on request).

Next, we have examined whether our findings are influenced by the inclusion of variables reflecting political-institutional conditions that have been suggested to affect fiscal policy. We checked the sensitivity of our results for the inclusion in specification III of Table 3 of variables reflecting i) the type of government, ii) the fractionalisation of government, and iii) the positioning of the government on a left-right scale.

Since Roubini and Sachs (1989), various studies have examined the impact of the type of government on fiscal policy outcomes. The basic idea is that coalition governments are weaker than single-party majoritarian governments and therefore will end up with higher deficits if the country concerned is hit by a negative economic shock. Roubini and Sachs (1989) present evidence in support of this view, but other studies reject the hypothesis (see, for example, De Haan and Sturm, 1997). To take the type of government into account, we construct a dummy which is one in case of a single-party government and zero in all other cases. It turned out that the dummy's coefficient was positive but highly insignificant with a p-value of 0.54 . The other results remained unchanged.

Perotti and Kontopoulos (2002) argue that the fractionalisation of government - measured by the number of political parties or the number of spending ministers in government - affects fiscal policy. The more fragmented the government, i.e. the higher the number of parties or spending ministers, the higher will be the budget deficit. There is quite some support for this view (see, for instance, Volkerink and de Haan, 2001). Therefore, the number of political parties in government as well as the number of spending ministers in government were separately included in the regressions. They both failed to reach significance (p-values of 0.18 and 0.91 , respectively) and did not affect the election effect.

Since several studies suggest that the political colour of a government affects fiscal policy outcomes (see Franzese, 2002 for a discussion) ${ }^{15}$, the influence of the government's positioning on a left-right scale was also taken into account. This was done by constructing the variable

\footnotetext{
${ }^{15}$ As Franzese (2000) puts it, at least since Hibbs (1977) political economists have argued that parties of the right and left differ in their fiscal policy priorities. Specifically, left-wing governments favor larger public economies, greater redistribution, and more Keynesian expansion and so are expected to run greater deficits than right-wing governments.
} 
GCOL, which uses a scaling from 1 for ultra-left to 20 for ultra-right governments. Data on party colour were obtained from Benoit and Laver (2005). The estimation results are presented in columns $\mathrm{V}$ and VI of Table 3. The political composition of the government indeed has a significant influence on the change in net lending. However, this influence is rather small. Again, adding this variable does not substantially affect the coefficient of our election variables.

Finally, some specific non-political variables were added to the model as a further robustness test. Some previous studies have suggested that there may be asymmetries in fiscal responses to recessions and upturns. For instance, Mayes and Viren (2000) argue that during recessions governments pursue expansionary fiscal policies to combat the downturn, while during economic upswings the proceeds are used for cutting taxes or increasing spending rather than for additional consolidation. Therefore, a dummy is constructed that is one in case of a positive change in the output gap and is zero otherwise. As it is highly insignificant, with a p-value of 0.77 , there is no reason to assume fiscal policy responds differently in magnitude to positive changes in the output gap than to negative changes. Including the variable did not affect our other results.

Also the debt-to-GDP ratio was added to the model as it may capture concerns on the sustainability of fiscal policy (Tujula and Wolswijk, 2004). From a sustainability perspective, increasing debt ratios should lead to an improvement in the budget balance. In fact, Melitz (2000) suggests the use of a quadratic formulation for the debt ratio as higher debt levels may induce more stabilizing fiscal reactions. However, a higher debt ratio also causes a rise in interest payments, resulting in a worsening of the fiscal balance. As a consequence, the overall effect of the debt ratio on budget balances is not a priori clear. Indeed, the coefficients of the level and the squared level of the debt-to-GDP ratio are insignificant with p-values between 0.15 and 0.22 . Again, the election effect remains unchanged.

\section{Conclusions}

As Buti and van den Noord (2003) point out, in the run-up to the monetary union the incentives for national policy makers to stick to the announced consolidation path were quite strong since failure of meeting the convergence criteria carried the penalty of exclusion from the euro area. This was considered too hard a political sanction. However, things may be different once a country has been admitted in the monetary union. That is, unlike the Maastricht convergence criteria, sticking to the rules of the SGP may not pay politically. This holds true especially for large countries (see De Haan et al., 2004). Moreover, the adoption of fiscal consolidation policies 
during the run-up to the monetary union might have created the room of manoeuvre for politically-motivated fiscal actions.

This paper examines whether there is a $\mathrm{PBC}$ in EU member countries in the euro area despite the adoption of the Stability and Growth Pact. We concentrate on EU members that have adopted the euro since the rules of the SGP are less strict for member countries that are not part of the currency union. We use a more sophisticated approach than previous studies that focused on the recent fiscal policy experience of EU member countries. Using data for the period 1999-2004 we find strong evidence that the SGP did not restrict policy makers in pursuing expansionary fiscal policies before elections. In an election year - but not in the year prior to the election - the budget deficit increases. This result is in line with third generation PBC models, which are based on moral hazard. We also find that fiscal policy is somewhat more expansionary under left-wing policy makers. 


\section{References}

Alesina, Albero, Nouriel Roubini and Gerald Cohen (1997) Political Cycles and the Macroeconomy. Cambridge, MA: MIT Press.

Alt, James E. and David Dreyer Lassen (2005) 'The Political Budget Cycle is Where You Can't See It: Transparency and Fiscal Manipulation', EPRU Working Paper No. 2005-03.

Amtenbrink, Fabian and Jakob De Haan (2003), 'Economic governance in the European Union Fiscal policy discipline versus flexibility', Common Market Law Review 40: 1075-1106.

Andrikopoulos, Andreas, Ioannis Loizides and Kyprianos Prodromidis (2004) 'Fiscal policy and political business cycles in the EU', European Journal of Political Economy 20: 125-152.

Benoit, Kenneth and Michael Laver (2005), Party policy in modern democracies. London: Routledge, forthcoming.

Block, Steven A. (2002) 'Political business cycles, democratization, and economic reform: the case of Africa', Journal of Development Economics 67: 205-228.

Brender, Adi (2003) 'The effect of fiscal performance on local government election results in Israel: 1989-1998', Journal of Public Economics 87(9-10): 2187-2205.

Brender, Adi and Allan Drazen (2005) 'Where Does the Political Business Cycle Really Come From?', Journal of Monetary Economics, forthcoming.

Budge, Ian, Hans-Dieter Klingemann, Andrea Volkens, Judith Bara and Eric Tanenbaum (2001) Mapping Policy Preferences: Estimates for Parties, Electors, and Governments, 1945-1998. Oxford: Oxford University Press.

Buti, Mario and Paul van den Noord (2003) 'Discretionary fiscal policy and elections: The experience of the early years of EMU', OECD Economics Department Working Paper, No. 351.

De Haan, Jakob and Jan-Egbert Sturm (1994) 'Political and institutional determinants of fiscal policy in the European Community', Public Choice 80: 157-172.

De Haan, Jakob and Jan-Egbert Sturm (1997) 'Political and Economic Determinants of OECD Budget Deficits and Government Expenditures: A Reinvestigation', European Journal of Political Economy 13: 739-750.

De Haan, Jakob, Helge Berger and David-Jan Jansen (2003) 'The End of the Stability and Growth Pact?', CESifo Working Paper, No. 1093.

De Haan, Jakob, Helge Berger and David-Jan Jansen (2004) 'Why Did the Stability and Growth Pact Fail?', International Finance 7 (2): 235-260.

Drazen, Allan (2000) 'The Political Business Cycle After 25 Years', in: Ben S. Bernanke and Kenneth S. Rogoff (eds) NBER Macroeconomic Annual. Cambridge, MA: MIT Press.

Drazen, Allan and Marcella Eslava (2003) 'Reconciling Fiscal Conservatism and Political Fiscal Cycles', University of Maryland, mimeo.

Franzese, Robert J. (2000) 'Electoral and Partisan Manipulation of Public Debt in Developed Democracies, 1956-1990', in Ralph Strauch, Jürgen von Hagen (eds), Institutions, Politics and Fiscal Policy, pp. 61-83. Dordrecht: Kluwer Academic Press.

Franzese, Robert J. (2002) 'Electoral and Partisan Cycles in Economic Policies and Outcomes', Annual Review of Political Science 5: 369-421.

Hibbs, Douglas (1977) 'Political Parties and Macroeconomic Policy', American Political Science Review 71(4): 1467-87.

Katz, Richard S. and Ruud Koole (1999) 'Political data yearbook 1999', European Journal of Political Research 36: 317-547.

Katz, Richard S. and Ruud Koole (2000) 'Political data yearbook 2000', European Journal of Political Research 38: 303-556.

Katz, Richard S. and Ruud Koole (2001) 'Political data yearbook 2001', European Journal of Political Research 40: 223-457.

Katz, Richard S. and Ruud Koole (2002) 'Political data yearbook 2002', European Journal of Political Research 41: 885-1118. 
Katz, Richard S. and Ruud Koole (2003), 'Political data yearbook 2003', European Journal of Political Research 42: 873-1123.

Mayes, David and Matti Viren (2000) 'Pressures on the Stability and Growth Pact from Asymmetry in Policy', Bank of Finland Discussion Paper, No. 11.

Melitz, Jacques (2000) 'Some Cross-Country Evidence about Fiscal Policy Behaviour and Consequences for EMU', European Economy 2: 3-21.

Nordhaus, William (1975) 'The political business cycle', Review of Economic Studies 42: 169190.

Perotti, Roberto and Yianos Kontopoulos (2002) 'Fragmented Fiscal Policy', Journal of Public Economics 86 (2): 191-222.

Persson, Torsten and Guido Tabellini (2000) Political Economics: Explaining Economic Policy. Cambridge, MA: MIT Press.

Persson, Torsten and Guido Tabellini (2002) 'Do Electoral Cycles Differ Across Political Systems?', working paper.

Rogoff, Kenneth S. (1990) 'Equilibrium political budget cycles', American Economic Review 80: 21-36.

Rogoff, Kenneth S. and Anne Sibert (1988) 'Elections and macroeconomic policy cycles', Review of Economic Studies 55: 1-16.

Roubini, Nouriel and Jeffrey Sachs (1989), 'Government Spending and Budget Deficits in the Industrialized Countries', Economic Policy Nr. 8: 99-132.

Schuknecht, Ludger S. (1996), 'Political Business Cycles in Developing Countries' Kyklos, 49: $155-70$.

Schuknecht, Ludger S. (2000) 'Fiscal policy cycles and public expenditures in developing countries' Public Choice, 102: 115-130.

Schuknecht, Ludger S. (2004) 'EU fiscal rules: issues and lessons from political economy', ECB Working Paper, No 421.

Shi, Min and Jakob Svensson (2002) 'Conditional Political Budget Cycles', CEPR Discussion Paper, No. 3352.

Shi, Min and Jakob Svensson (2004) 'Political Budget Cycles: A Review of Recent Developments', mimeo.

Tujula, Mika and Guido Wolswijk (2004) 'What determines fiscal balances? An empirical investigation in determinants of changes in OECD budget balances', ECB Working Paper, No 422.

Van Biezen, Ingrid and Richard S. Katz (2004) 'Political data yearbook 2004', European Journal of Political Research 43: 919-1175.

Volkerink, Bjørn and Jakob De Haan (2001) 'Fragmented Government Effects on Fiscal Policy: New Evidence', Public Choice, 109: 221-242.

von Hagen, Jürgen (2003) 'Fiscal discipline and growth in Euroland. Experiences with the Stability and Growth Pact', ZEI Working Paper, No. B062003. 


\section{Appendix: Data sources}

(Cyclically adjusted) net lending. Statistics on general government net lending and cyclically adjusted net lending were obtained from the Statistical Annex to European Economy, published in spring 2005. Statistics for 1998, which were necessary to calculate the change in net lending for 1999, were obtained from Eurostat.

Forecasting errors in GDP growth rates and inflation. Statistics regarding outcomes of GDP growth and GDP deflators were obtained from the Statistical Annex to European Economy, published in spring 2005. Forecasts on these variables were obtained from the countries' stability programmes as published one year in advance. In order to ensure that time intervals between forecast and realisation dates are comparable across the sample, forecasts from stability programmes published after January of the year under consideration were not used. They were substituted by European Commission Autumn Forecasts presented in issues of European Economy that were published during the year preceding the year under consideration. This way, 7 out of 72 observations were replaced.

Output gap. Statistics regarding output gaps based on trend and potential GDP were obtained from the Statistical Annex to European Economy, published in spring 2005.

General election dates and cabinet crises. Statistics for 1998 to 2003 are obtained from political data yearbooks (Katz and Koole $(1999,2000,2001,2002,2003)$ and Van Biezen and Katz (2004)). Election data for 2004 were obtained from the online version of the Europa Yearbook (http://www.europaworld.com).

Type of government and government fractionalisation. Statistics on the number of parties and ministers in the government were obtained from the same sources used to obtain data on election dates and cabinet crises. In case a change of government occurred during the year, averages were taken using the percentage of the year during which each government was in power. In calculating the number of parties, independent cabinet members were excluded. In calculating the number of ministers, finance ministers or ministers for the budget were excluded. Junior ministers, secretaries of state and ministers to the prime minister were not taken into account either.

Government positioning on a left-right scale. Data on party colour were obtained from Benoit and Laver (2005). However, for France data from the Comparative Manifestos Project (Budge et al., 2001) was used, which did not affect the results. In fact, using only the CMP data in constructing the variable leads to identical conclusions.

Debt to GDP ratio. Statistics on debt ratios were obtained from the Statistical Annex to European Economy, published in spring 2005. 


\section{CESifo Working Paper Series}

(for full list see www.cesifo-group.de)

1469 Torberg Falch and Marte Rønning, The Influence of Student Achievement on Teacher Turnover, May 2005

1470 John Komlos and Peter Salamon, The Poverty of Growth with Interdependent Utility Functions, May 2005

1471 Hui Huang, Yi Wang, Yiming Wang, John Whalley and Shunming Zhang, A Trade Model with an Optimal Exchange Rate Motivated by Current Discussion of a Chinese Renminbi Float, May 2005

1472 Helge Holden, Lars Holden and Steinar Holden, Contract Adjustment under Uncertainty, May 2005

1473 Kai A. Konrad, Silent Interests and All-Pay Auctions, May 2005

1474 Ingo Vogelsang, Electricity Transmission Pricing and Performance-Based Regulation, May 2005

1475 Spiros Bougheas and Raymond Riezman, Trade and the Distribution of Human Capital, June 2005

1476 Vesa Kanniainen, Seppo Kari and Jouko Ylä-Liedenpohja, The Start-Up and Growth Stages in Enterprise Formation: The "New View" of Dividend Taxation Reconsidered, June 2005

1477 M. Hashem Pesaran, L. Vanessa Smith and Ron P. Smith, What if the UK had Joined the Euro in 1999? An Empirical Evaluation Using a Global VAR, June 2005

1478 Chang Woon Nam and Doina Maria Radulescu, Effects of Corporate Tax Reforms on SMEs' Investment Decisions under the Particular Consideration of Inflation, June 2005

1479 Panos Hatzipanayotou, Sajal Lahiri and Michael S. Michael, Globalization, CrossBorder Pollution and Welfare, June 2005

1480 John Whalley, Pitfalls in the Use of Ad valorem Equivalent Representations of the Trade Impacts of Domestic Policies, June 2005

1481 Edward B. Barbier and Michael Rauscher, Trade and Development in a Labor Surplus Economy, June 2005

1482 Harrie A. A. Verbon and Cees A. Withagen, Tradable Emission Permits in a Federal System, June 2005

1483 Hendrik Hakenes and Andreas Irmen, On the Long-Run Evolution of Technological Knowledge, June 2005 
1484 Nicolas Schmitt and Antoine Soubeyran, A Simple Model of Brain Circulation, June 2005

1485 Carsten Hefeker, Uncertainty, Wage Setting and Decision Making in a Monetary Union, June 2005

1486 Ondřej Schneider and Jan Zápal, Fiscal Policy in New EU Member States - Go East, Prudent Man!, June 2005

1487 Christian Schultz, Virtual Capacity and Competition, June 2005

1488 Yvan Lengwiler and Elmar Wolfstetter, Bid Rigging - An Analysis of Corruption in Auctions, June 2005

1489 Johannes Becker and Clemens Fuest, Does Germany Collect Revenue from Taxing Capital Income?, June 2005

1490 Axel Dreher and Panu Poutvaara, Student Flows and Migration: An Empirical Analysis, June 2005

1491 Bernd Huber and Marco Runkel, Interregional Redistribution and Budget Institutions under Asymmetric Information, June 2005

1492 Guido Tabellini, Culture and Institutions: Economic Development in the Regions of Europe, July 2005

1493 Kurt R. Brekke and Michael Kuhn, Direct to Consumer Advertising in Pharmaceutical Markets, July 2005

1494 Martín Gonzalez-Eiras and Dirk Niepelt, Sustaining Social Security, July 2005

1495 Alfons J. Weichenrieder, (Why) Do we need Corporate Taxation?, July 2005

1496 Paolo M. Panteghini, S-Based Taxation under Default Risk, July 2005

1497 Panos Hatzipanayotou and Michael S. Michael, Migration, Tied Foreign Aid and the Welfare State, July 2005

1498 Agata Antkiewicz and John Whalley, BRICSAM and the Non-WTO, July 2005

1499 Petr Hedbávný, Ondřej Schneider and Jan Zápal, A Fiscal Rule that has Teeth: A Suggestion for a 'Fiscal Sustainability Council' underpinned by the Financial Markets, July 2005

1500 J. Atsu Amegashie and Marco Runkel, Sabotaging Potential Rivals, July 2005

1501 Heikki Oksanen, Actuarial Neutrality across Generations Applied to Public Pensions under Population Ageing: Effects on Government Finances and National Saving, July 2005 
1502 Xenia Matschke, Costly Revenue-Raising and the Case for Favoring Import-Competing Industries, July 2005

1503 Horst Raff and Nicolas Schmitt, Why Parallel Trade may Raise Producers Profits, July 2005

1504 Alberto Bisin and Piero Gottardi, Efficient Competitive Equilibria with Adverse Selection, July 2005

1505 Peter A. Zadrozny, Necessary and Sufficient Restrictions for Existence of a Unique Fourth Moment of a Univariate GARCH(p,q) Process, July 2005

1506 Rainer Niemann and Corinna Treisch, Group Taxation, Asymmetric Taxation and Cross-Border Investment Incentives in Austria, July 2005

1507 Thomas Christiaans, Thomas Eichner and Ruediger Pethig, Optimal Pest Control in Agriculture, July 2005

1508 Biswa N. Bhattacharyay and Prabir De, Promotion of Trade and Investments between China and India: The Case of Southwest China and East and Northeast India, July 2005

1509 Jean Hindriks and Ben Lockwood, Decentralization and Electoral Accountability: Incentives, Separation, and Voter Welfare, July 2005

1510 Michelle R. Garfinkel, Stergios Skaperdas and Constantinos Syropoulos, Globalization and Domestic Conflict, July 2005

1511 Jesús Crespo-Cuaresma, Balázs Égert and Ronald MacDonald, Non-Linear Exchange Rate Dynamics in Target Zones: A Bumpy Road towards a Honeymoon - Some Evidence from the ERM, ERM2 and Selected New EU Member States, July 2005

1512 David S. Evans and Michael Salinger, Curing Sinus Headaches and Tying Law: An Empirical Analysis of Bundling Decongestants and Pain Relievers, August 2005

1513 Christian Keuschnigg and Martin D. Dietz, A Growth Oriented Dual Income Tax, July 2005

1514 Fahad Khalil, David Martimort and Bruno Parigi, Monitoring a Common Agent: Implications for Financial Contracting, August 2005

1515 Volker Grossmann and Panu Poutvaara, Pareto-Improving Bequest Taxation, August 2005

1516 Lars P. Feld and Emmanuelle Reulier, Strategic Tax Competition in Switzerland: Evidence from a Panel of the Swiss Cantons, August 2005

1517 Kira Boerner and Silke Uebelmesser, Migration and the Welfare State: The Economic Power of the Non-Voter?, August 2005 
1518 Gabriela Schütz, Heinrich W. Ursprung and Ludger Wößmann, Education Policy and Equality of Opportunity, August 2005

1519 David S. Evans and Michael A. Salinger, Curing Sinus Headaches and Tying Law: An Empirical Analysis of Bundling Decongestants and Pain Relievers, August 2005

1520 Michel Beine, Paul De Grauwe and Marianna Grimaldi, The Impact of FX Central Bank Intervention in a Noise Trading Framework, August 2005

1521 Volker Meier and Matthias Wrede, Pension, Fertility, and Education, August 2005

1522 Saku Aura and Thomas Davidoff, Optimal Commodity Taxation when Land and Structures must be Taxed at the Same Rate, August 2005

1523 Andreas Haufler and Søren Bo Nielsen, Merger Policy to Promote 'Global Players'? A Simple Model, August 2005

1524 Frederick van der Ploeg, The Making of Cultural Policy: A European Perspective, August 2005

1525 Alexander Kemnitz, Can Immigrant Employment Alleviate the Demographic Burden? The Role of Union Centralization, August 2005

1526 Baoline Chen and Peter A. Zadrozny, Estimated U.S. Manufacturing Production Capital and Technology Based on an Estimated Dynamic Economic Model, August 2005

1527 Marcel Gérard, Multijurisdictional Firms and Governments' Strategies under Alternative Tax Designs, August 2005

1528 Joerg Breitscheidel and Hans Gersbach, Self-Financing Environmental Mechanisms, August 2005

1529 Giorgio Fazio, Ronald MacDonald and Jacques Mélitz, Trade Costs, Trade Balances and Current Accounts: An Application of Gravity to Multilateral Trade, August 2005

1530 Thomas Christiaans, Thomas Eichner and Ruediger Pethig, A Micro-Level 'Consumer Approach' to Species Population Dynamics, August 2005

1531 Samuel Hanson, M. Hashem Pesaran and Til Schuermann, Firm Heterogeneity and Credit Risk Diversification, August 2005

1532 Mark Mink and Jakob de Haan, Has the Stability and Growth Pact Impeded Political Budget Cycles in the European Union?, September 2005 